\title{
PENGARUH KOMPOSISI BATUBARA TERHADAP KARAKTERISTIK PEMBAKARAN DAUN CENGKEH SISA DESTILASI MINYAK ATSIRI
}

\author{
Nur Aklis \\ Teknik Mesin Universitas Muhammadiyah Surakarta \\ Jl. A.Yani Tromol Pos I Pabelan, Kartasura \\ email:nur_aklis@ums.ac.id
}

\begin{abstract}
ABSTRAK
Limbah proses destilasi (penyulingan) minyak atsiri daun cengkeh yang berupa daun cengkeh kering sering dianggap sebagai limbah industri dan kurang dimanfaatkan. Penggunaan daun cengkeh kering sisa proses destilasi minyak atsiri hanya digunakan sebagai pendukung dari bahan bakar proses tersebut dengan dibakar secara langsung. Penelitian ini bertujuan untuk mengetahui karakteristik pembakaran daun cengkeh sisa destilasi jika padukan dengan batubara dengan beberapa variasi dalam bentuk briket.

Penelitian diawali dengan pengumpulan bahan dasar berupa daun cengkeh sisa proses destilasi, batubara lignit dan aspal sebagai perekat, daun cengkeh dan batubara kemudian dihancurkan dan selanjutnya dicampur dengan binder berupa aspal. Variasi yang digunakan adalah variasi komposisi, yaitu 100\% batubara, 100\% daun cengkeh, $80 \%$ batubara dan 20\% daun cengkeh, $60 \%$ batubara dan $40 \%$ daun cengkeh, $40 \%$ batubara dan $60 \%$ daun cengkeh, dan semuanya menggunakan binder aspal dengan komposisi 10\% dari berat total briket dan ditekan dengan tekanan sebesar $250 \mathrm{~kg} / \mathrm{cm}^{2}$. Pengujian karakteristik pembakaran dilaksanakan untuk mengetahui temperatur, massa sisa dan laju pembakaran yang dihasilkan oleh campuran batubara dan daun cengkeh. Pengujian ini dilakukan pada sebuah tungku pembakaran dan pengambilan data dilakukan setiap 1 menit.

Hasil penelitian menunjukkan bahwa variasi komposisi berpengaruh pada karakteristik pembakaran. Penambahan batubara akan mempertinggi temperatur pembakaran dan memperlama waktu pembakaran.Waktu pembakaran paling lama mencapai 44 menit dan tempertur tertinggi hingga $304^{\circ} \mathrm{C}$ yang dimiliki biobriket dengan komposisi 100\% batubara.
\end{abstract}

Kata Kunci: daun cengkeh, batubara, variasi komposisi

\section{PENDAHULUAN}

Minyak bumi adalah energi yang tidak dapat diperbarui, tetapi dalam kehidupan seharihari bahan bakar minyak masih menjadi pilihan utama sehingga akan mengakibatkan menipisnya cadangan minyak bumi di dalam bumi.Sementara batu-bara dan gas bumi belum dimaksimalkan pemanfaatannya untuk konsumsi dalam negeri.
Limbah industri yang selama ini sering menimbulkan permasalahan. Sebab menjadi salah satu penyebab pencemaran lingkungan. Begitu pula limbah dari pabrik-pabrik yang berbahan dasar sumber daya alam hayati. Sebagai contohnya daun cengkeh kering sisa proses destilasi minyak atsiri.

Minyak cengkeh merupakan salah satu produkunggulan Kabupaten Boyolali disamping 

- Temperatur penyalaan (Ignition Temperature)

- Ukuran Batubara

Briket batubara adalah bahan bakar padat yang terbuat dari batubara dengan sedikit campuran perekat. Briket Batubara mampu menggantikan sebagian dari kegunaan minyak tanah sepeti untuk pengolahan makanan, pengeringan, pembakaran dan pemanasan. Bahan baku utama briket batubara adalah batubara yang sumbernya berlimpah di Indonesia dan mempunyai cadangan untuk selama lebih kurang 150 tahun. Teknologi pembuatan briket tidaklah terlalu rumit dan dapat dikembangkan oleh masyarakat maupun pihak swasta dalam waktu singkat.

\section{METODE PENELITIAN}

Diagram Alir Penelitian dapat dilihat pada gambar 1 sebagai berikut.

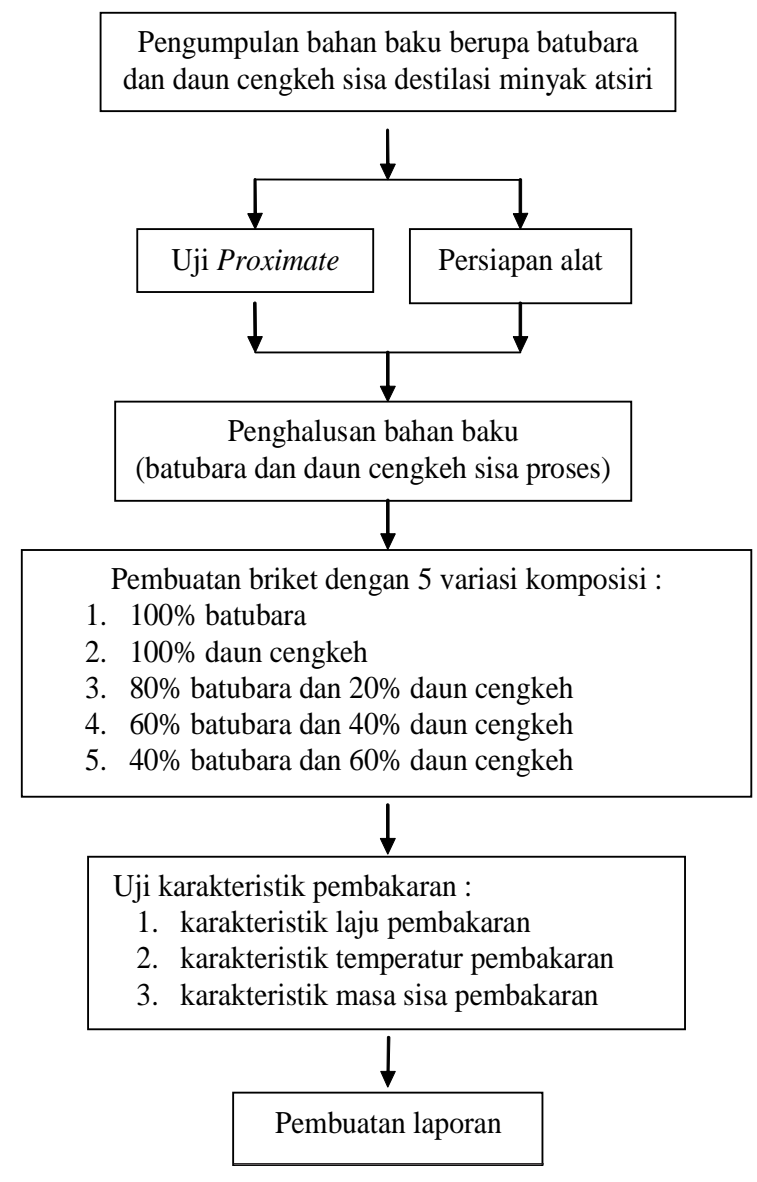

Gambar 1. Diagram Alir Penelitian berikut,

Alur penelitian dapat dijelaskan sebagai

1. Pengumpulan Bahan Baku

Bahan baku yang digunakan adalah daun cengkeh sisa proses penyulingan dan batubara. Sebagai bahan pengikat dipilih aspal.

2. Pengujian Bahan Baku

B ahan baku yang sudah terkumpul diuji di Laboratorium KimiaAnalitik dan Laboratorium Pusat Studi Pangan dan Gizi Universitas Gajah Mada.

3. Pengolahan Bahan Baku

Proses dilakukan sebagai persiaapan pembuatan briket.

4. Pembuatan Briket

Briket dibuat dengan perbandingan komposisi $100 \%$ batubara, $100 \%$ daun cengkeh, $80 \%$ batubara : $20 \%$ daun cengkeh, $60 \%$ batubara: $40 \%$ daun cengkeh, dan $40 \%$ batubara: $60 \%$ daun cengkeh. Bioriket dibuat dengan ukuran diameter 2,8 dan dengan berat 5 gram. Briket dapat dilihat pada gambar 2.

5. Uji Karakteristik Pembakaran

Pengujian Pembakaran bertujuan untuk mengetahui karakteristik pembakaran biobriket. Pengujian ini dilakukan pada sebuah tungku pembakaran.Pengambilan data dilakukan setiap 1 menit.

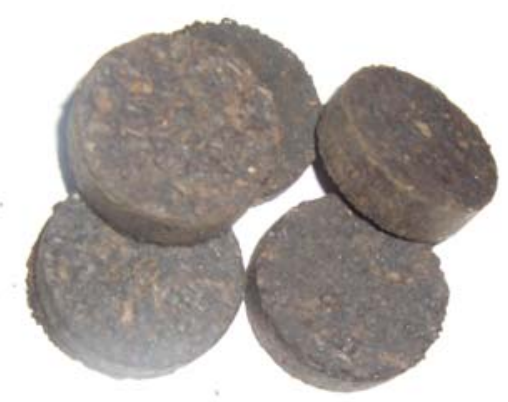

Gambar 2. Briket Pengujian

\section{Alat Pengujian}

Pengujian dilakukan di alat uji pembakaran yang terdapat di Laboratorium Konversi Energi Teknik Mesin UMS dengan bantuan alat ukur stpwatch, termokopel reader. Skema alat uji dapat dilihat pada gambar 3 


\section{Hasil pengujian Pembakaran}

\section{Karakteristik Temperatur Pembakaran}

\section{Gambar 3. Skema Alat Uji}

Keterangan :

$\rightarrow . . . . . . . . \rightarrow$ : Aliran udara

1. Blower

2. Saluran by pass

3. Katup pengatur aliran udara

4. Tungku 1

5. Tungku 2

6. Termokopel temperatur uadara

7. Termokopel temperatur udara pre-heater

8. Digital termocouple reader

9. Termokopel temperatur briket

10. Termokopel temperatur dinding

11. Kawat ke timbangan digital

12. Electronik profesional scale (timbangan digital

\section{HASIL DAN PEMBAHASAN}

\section{Hasil Pengujian Kandungan Bahan Dasar}

\section{Karakteristik Bahan Baku}

Tabel 1. menunjukkan kandungan bahan dasar daun cengkeh sisa destilasi. Kandungan volatile matter yang tinggi akan mempermudah penyalaan dan kadar kalori yang tinggi akan menyebabkan temperatur pembakaran yang tinggi.

\section{Tabel 1. Kandungan Bahan Baku}

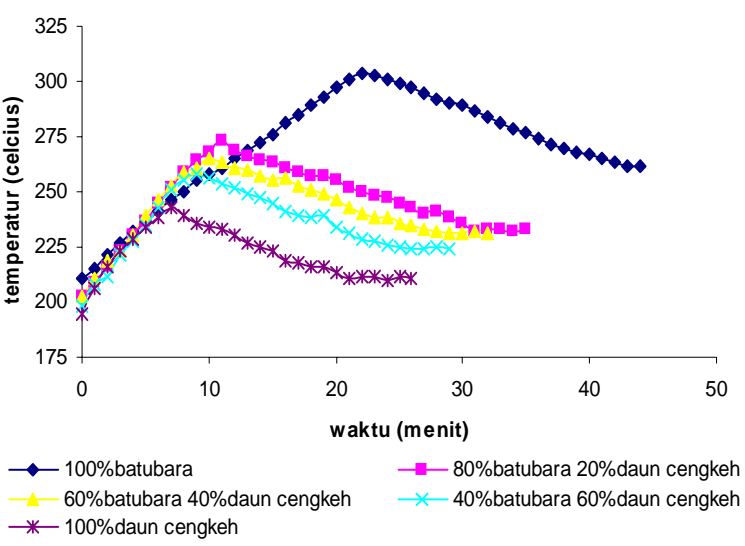

\section{Gambar 4. Karakteristik Temperatur Pembakaran Biobriket}

Gambar 4. menunjukkan hubungan antara temperatur pembakaran terhadap waktu Pada pembakaran briket dengan komposisi 100\% daun cengkehmenghasilkan temperatur tertinggi pada temperatur 243 dalam waktu 7 menit, briket dengan komposisi 40\% batubara dan 60\% daun cengkeh menghasilkan temperatur tertinggi pada temperatur 258 dalam waktu 9 menit, briket dengan komposisi 60\% batubara dan $40 \%$ daun cengkeh mampu menghasilkan temperatur tertinggi pada temperatur 265 dalam waktu 10 menit, briket dengan komposisi 80\% batubara dan $20 \%$ daun cengkeh mampu menghasilkan temperatur tertinggi pada temperatur 273 dalam waktu 11menit dan temperatur tertinggi dihasilkan oleh briket dengan komposisi 100\% batubara pada temperatur 304 dalam waktu 22 menit. Perbedaan pencapaian temperatur tertinggi pada tiap biobriket berbeda.

Semakin banyak batubara dalam biobriket maka akan menyebabkan semakin tingginya temperatur pembakaran yang dihasilkan. Tinggi temperatur dipengaruhi oleh kandungan kalori dan kadar karbon terikat (fixed carbon).

\section{Karakteristik Massa Sisa Pembakaran}

Gambar 5. menunjukkan hubungan antara massa sisa dengan wakyu. Dalam gambar terse- 


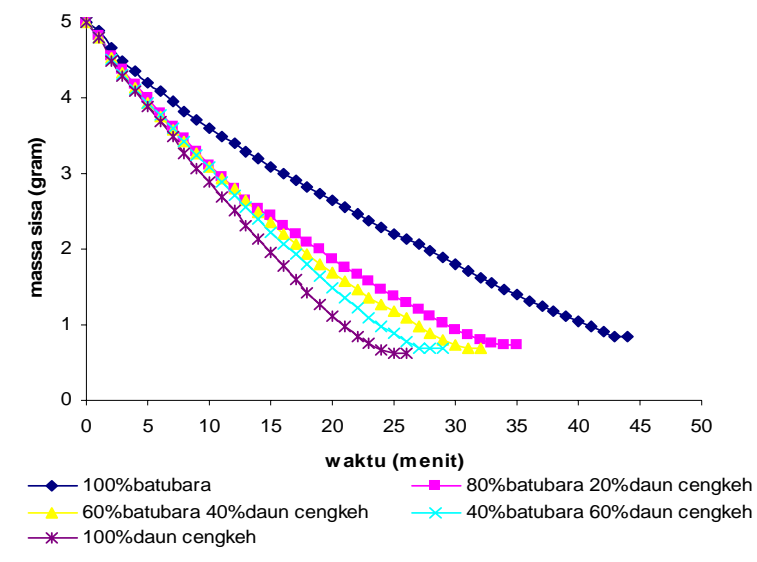

Gambar 5. Karakteristik Massa Sisa Pembakaran Biobriket

but terlihat bahwa briket dengan komposisi 100\% batubara mempunyai massa sisa 0.85gram pada menit ke-43, briket dengan komposisi 80\% batubara dan $20 \%$ daun cengkeh mempunyai massa sisa 0.74 gram pada menit ke-34, briket dengan variasi komposisi $60 \%$ batubara dan $40 \%$ daun cengkeh mempunyai massa sisa 0.7 gram pada menit ke-31, briket dengan komposisi 40\% batubara dan $60 \%$ daun cengkeh mempunyai massa sisa 0.68 gram pada menit ke-28, dan briket dengan komposisi 100\% daun cengkeh mempunyai massa sisa 0.62gram pada menit ke-25.

Briket pada waktu pembakaran nol menit mempunyai massa yang sama sebesar 5 gram. Pada pembakaran terlihat adanya gejala pengurangan massa yang berbeda antara komposisi satu dengan yang lain. Semakin lama waktu pembakaran maka semakin jelas adanya perbedaan pengurangan massa.

Semakin tinggi prosentase batubara dalam komposisi briket maka briket semakin banyak sisa pembakarannya atau abu yang terbentuk dan sebaliknya semakin tinggi prosentase daun cengkeh maka akan semakin sedikit abu yang terbentuk.

\section{Karakteristik Laju Pembakaran}

Setelah mengetahui dan menganalisis hubungan pengurangan massa briket terhadap waktu, selanjutnya dapat dilakukan perhitungan laju pembakaran. Gambar 6 menunjukkan pe- ngaruh komposisi briket terhadap laju pembakaran. Dasar dari perhitungan laju pembakaran adalah data massa sisa.

Gambar 3 menunjukkan briket dengan komposisi 100\% daun cengkeh mempunyai laju pembakaran tertinggi pada menit ke-2 dengan laju pembakaran 0.31gram/menit. Briket dengan komposisi $40 \%$ batubara dan daun 60\% cengkeh mempunyai laju pembakaran tertinggi pada menit ke 2 dengan laju pembakaran 0.29 gram/menit, briket dengan komposisi 60\% batubara dan 40\%daun cengkeh mempunyai laju pembakaran tertinggi pada menit ke 2 dengan laju pembakaran 0.27 gram/menit.

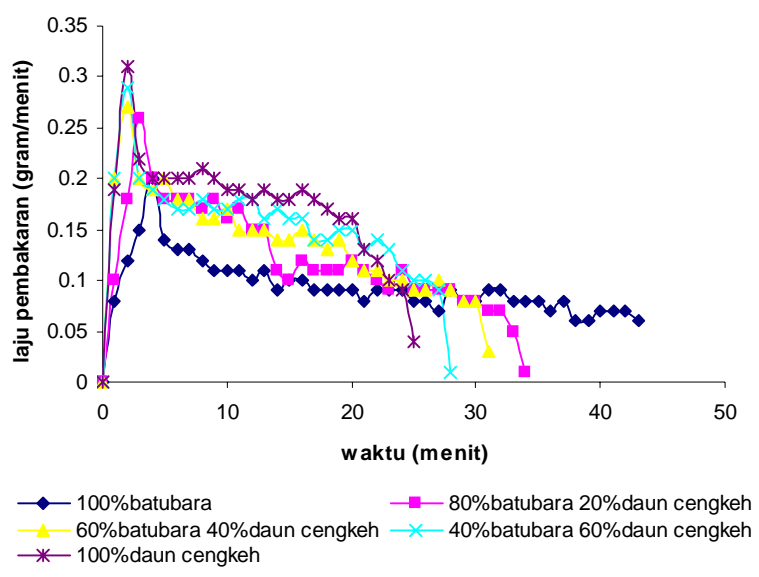

\section{Gambar 6. Karakteristik Laju Pembakaran Biobriket}

Briket dengan komposisi 80\% batubara dan 20\% daun cengkeh mempunyai laju pembakaran tertinggi pada menit ke 3 dengan laju pembakaran 0.26gram/menit dan briket dengan komposisi 100\% batubara mendapatkan laju pembakaran tertinggi pada menit ke 4 dengan laju pembakaran 0.20gram/menit.

Dari terlihat laju pembakaran yang hampir sama terjadi pada komposisi $80 \%$ batubara $20 \%$ daun cengkeh, $60 \%$ batubara $40 \%$ daun cengkeh, dan $40 \%$ batubara $60 \%$ daun cengkeh, dan ini terjadi pada menit ke-3 sampai menit ke13, akan tetapi pada menit ke-14 pada komposisi $80 \%$ batubara $20 \%$ daun cengkeh terjadi penurunan laju pembakaran yang cukup besar, Ini terjadi karena tingkat homogenitas campuran batubara dan daun cengkeh, sehingga 
pada sisi yang banyak terdapat kandungan daun cengkeh maka akan terbakar terlebih dahulu. Ini juga menjelaskan bahwa kandungan zat volatile matter akan sangat berpengaruh dalam kecepatan pembakaran dan mempengaruhi waktu pembakaran itu sendiri.

Waktu yang dibutuhkan briket dalam mencapai laju pembakaran tertingginya berbedabeda. Laju pembakaran dipengaruhi oleh sifat dasar dari daun cengkeh yang mudah terbakar, semakin banyak massa yang terbakar laju pembakarannya akan semakin tinggi. Dimana nilai volatile matter yang tinggi akan mempermudah proses pembakaran biobriket.

Dengan naiknya kadar batubara dalam biobriket maka kadar fixed karbon akan semakin meningkat sehingga biobriket akan sulit terbakar dan memakan waktu yang cukup lama untuk proses pembakarannya.

\section{KESIMPULAN}

1. Semakin banyak komposisi batubara dalam briket akan menyebabkan semakin tinggi temperatur yang dapat dicapai dalam proses pembakaran.

2. Semakin banyak kandungan abu dalam briket maka akan menyebabkan massa sisa briket akan semakin banyak.

3. Semakin banyak kandungan volatile matter dalam briket maka akan menyebabkan laju pembakaran yang semakin singkat.

\section{PERSANTUNAN}

Terima kasih kami ucapkan kepada Direktorat Penelitian dan Pengabdian Masyarakat (DP2M) Ditjen Pendidikan Tinggi Dinas Pendidikan Nasionanal yang telah mendanai penelitian ini melalui hibah Dosen Muda.

\section{DAFTAR PUSTAKA}

Herbawamurti, T E., 2005. Pemanfaatan Energi Batubara. Badan Pengajian dan Penerapan Teknologi, Departemen Pendidikan Nasional, Jakarta.

Sukandarrumidi, 1995. Batubara dan Gambut. Gajah Mada University Press, Yogyakarta.

Pitono, 2007. Analisis Karakteristik Pembakaran Campuran Biobriket Enceng Gondak dan Batubara Dengan Variasi Komposisi. Tugas Akhir S1. Teknik Mesin Universitas Muhammadiyah Surakarta, Surakarta. 